Original Article

Received February 2022 / Revised February 2022 / Accepted February 2022

\title{
ANALISIS RESPON PENONTON MELALUI DISEMINASI ONLINE PENDIDIKAN LITERASI VLOG FAMILY SANITARY
}

Sulasfiana Alfi Raida ${ }^{1 *}$, Ma'ruf Al Haris², Ayu Amaliana Dewi ${ }^{3}$, Rizqi Handayani ${ }^{4}$, Novi Lailatul Fitriani ${ }^{5}$, Roviana Istiqomah ${ }^{6}$, Toyib Wahyu Nugroho ${ }^{7}$

1,2,3,4,5,6,7Program Studi Tadris IImu Pengetahuan Alam, Fakultas Tarbiyah, Institut Agama Islam Negeri Kudus, Jawa Tengah 59311

*Korespondensi: sulasfiana@iainkudus.ac.id

Abstrak. Sosialisasi Family Sanitary memiliki peran penting dalam proses untuk meningkatkan kemandirian masyarakat dalam kesehatan dan hidup sehat serta dapat mewujudkan perilaku sanitasi kesehatan untuk mencegah penyakit. Rumusan masalahan dari penelitian ini adalah "Bagaimana respon penonton pada sosialisasi literasi sains Family Sanitary tentang tips mencuci tangan dengan sabun via YouTube?". Metode penelitian yang digunakan adalah metode penelitian kuantitatif (Quantitative Research). Metode ini menjadi metode penelitian yang dipilih dalam penelitian ini untuk mengetahui respon penonton pada sosialisasi literasi sains Family Sanitary tentang tips mencuci tangan dengan sabun. Penelitian yang telah dilakukan melalui video vlog family sanitary dapat diambil kesimpulan bahwa strategi sosialisasi melalui YouTube mendapat respon baik dari warganet. Terlihat dari komentar-komentar yang positif dari warganet dan juga like serta tanpa adanya dislike

Kata Kunci: Desiminasi, Literasi, Family Sanitary

DOI: http://dx.doi.org/10.55241/spibio.v3i1.58 


\section{Pendahuluan}

Upaya kesehatan lingkungan merupakan salah satu cara yang dilakukan untuk mewujudkan kualitas lingkungan yang sehat, baik fisika, kimia, biologi dan sosial yang memungkinkan setiap masyarakat mencapai derajat kesehatan yang setinggi-tingginya. Lingkungan sehat mencakup lingkungan permukiman, tempat kerja, tempat rekreasi, serta tempat dan fasilitas umum. Sanitasi dasar merupakan syarat kesehatan lingkungan minimal yang harus dipunyai oleh setiap masyarakat untuk memenuhi keperluan sehari-hari. Ruang lingkup sanitasi dasar yakni sarana penyedian air bersih, sarana jamban keluarga, sarana pembuangan sampah, dan sarana pembuangan air limbah (Roat: 2018).

Sanitasi sendiri merupakan salah satu faktor penting yang mempengaruhi peningkatan derajat kesehatan manusia. Pemenuhan fasilitas sanitasi dasar dapat memberikan dampak positif bagi para penggunanya. Namun, di Indonesia penyediaan sanitasi masih belum sepenuhnya diterapkan oleh masyarakat. Apalagi jika melihat masih adanya masyarakat yang belum memiliki pemikiran akan akan pentingnya sanitasi bagi hidupnya, sehingga masih tinggi angka kesakitan akibat sanitasi yang buruk dan masih banyak pula masyarakat yang belum memiliki fasilitas sanitasi yang sesusai dengan syarat dan kriteria yang telah ditetapkan oleh pemerintah (Celesta: 2016)

Upaya yang dapat di lakukan untuk menciptakan masyarakat yang sadar akan lingkungan sekitar yang sehat dilakukan untuk menciptakan dan memelihara lingkungan akan terhindar dari penyakit dan masalah kesehatan lain dapat dilakukan dengan mengacu podoman pada teknis dari Kementrian Kesehatan.
Kegiatan penyehatan lingkungan mengacu pada Keputusan Menteri Kesehatan Nomor 1529/Menkes/SK/X/2010 tentang pedoman Umum Pengembangan Desa dan Kelurahan Siaga Aktif yaitu: sosialisasi tentang pentingnya sanitasi dasar kepada masyarakat desa, bantuan pemenuhan kebutuhan sarana dan prasarana dasar meliputi air bersih, jamban, pembuangan sampah dan limbah. Serta bantuan fasiliatas pencegahan pencemaran lingkungan.

Akses masyarakat terhadap informasi kesehatan sendiri belumlah merata, untuk dapat mewujudkan kemandirian dan kesadaran masyarakat di bidang kesehatan dilakukan kegiatan promosi kesehatan sebagai upaya peningkatan partisipasi masyarakat dibidang kesehatan. Untuk itu perlu adanya desiminasi online yang menyajikan suatu upaya penanganan yang menumbuhkan kesadaran akan pentingnya Family Sanitary. Desiminasi (Desimination) adalah suatu kegiatan yang ditujukan kepada kelompok target atau individu agar meraka memperoleh informasi, timbul kesadaran, menerima dan akhirnya memanfaatkan informasi tersebut. Diseminasi merupakan tindak inovasi yang disusun dan disebarkannya berdasarkan sebuah perencanaan yang matang dengan pandangan jauh ke depan baik melalui diskusi atau forum lainnya yang sengaja diprogramkan, sehingga terdapat kesepakatan untuk melaksanakan inovasi.

Perkembangan zaman yang serba modern dengan kemajuan teknologi yang sudah sangat pesat seperti saat ini, smartphone memiliki daya tarik tersendiri bagi pemiliknya. Melalui berbagai fitur-fitur yang telah tersedia, salah satunya adalah YouTube. YouTube adalah situs video 
online yang menyediakan berbagai informasi berupa gambar bergerak dan bisa diandalkan. youTube disediakan bagi siapapun yang akan mencari berbagai informasi video. Sesuai dengan jenis-jenis media sosial, YouTube termasuk ke dalam jenis media sharing. Pemanfaatan YouTube lebih nyata dan langsung aplikatif terhadap berbagai keperluan dan kebutuhan pengguna salah satunya mengakses dan berbagi informasi seputar hal-hal teknis. Banyak pengguna yang mengakses YouTube untuk mengetahui cara-cara melakukan berbagai hal, seperti tips mencuci tangan yang baik dan benar, cara menggunakan aplikasi dalam komputer atau telepon pintar, demo memasak, mengolah sampah, memanfaatkan barang bekas menjadi harga jual yang ekonomis, dan lain sebagainya.

Selain sebagai konten sharing, YouTube juga dimanfaatkan sebagi media literasi berbasis digital terutama keluarga. Literasi digital merupakan hal penting yang dibutuhkan untuk dapat berpartisipasi di dunia modern sekarang ini. Literasi digital sama pentingnya dengan membaca, menulis, berhitung dan disiplin ilmu lainya termasuk sains. Literasi sains dapat diartikan sebagai pengetahuan dan kecakapan ilmiah untuk mampu mengidentifikasi

memperoleh pengetahuan baru, menjelaskan fenomena ilmiah, serta mengambil simpulkan berdasarkan fakta, memahami karakteristik sains,

\section{Metode}

Metode penelitianyang digunakan adalahmetode penelitian kuantitatif (Quantitative Research). Metode kuantitatif merupakan pendekatam penelitian yang dalam menjawab permasalahan penelitian memerlukan pengukuran yang cermat terhadap kesadaran bagaimana sains dan teknologi membentuk lingkungan alam, intelektual, dan budaya serta kemauan untuk terlibat dan peduli terhadap isu-isu terkait dengan sains (Kementerian Pendidikan dan Kebudayaan, 2017).

Sedangkan dengan adanya pandemi covid 19 seperti ini, sosialisasi Family Sanitarydilakukan secara daring untuk menghindari keramaian yang terjadi di lingkungan sekitar. Dengan melalui video vlog YouTube agar dapat memberikan berbagai tips kepada masyarakat, agar menjaga kebersihan baik diri sendiri maupun lingkungan sekitar untuk membiasakan hidup sehat dan dapat terhindar dari adanya pandemi covid 19 (World Health Organization, 2020). Upaya sosialisasi Family Sanitary memiliki peran penting dalam proses untuk meningkatkan kemandirian masyarakat dalam kesehatan dan hidup sehat seta dapat mewujudkan perilaku sanitasi kesehatan untuk mencegah penyakit akibat sanitasi lingkungan yang dipengaruhi oleh kondisi lingkungan sosail budayanya. Dari pemikiran di atas maka penulis mengangkat permasalahan tersebut dalam penelitian dengan judul "Analisis Respon Penonton Diseminasi Online Pendidikan Literasi Vlog Family Sanitary" dengan tujuan "Untuk mengetahui respon penonton pada sosialisasi literasi sains Family Sanitary tentang tips mencuci tangan dengan sabun via YouTube".

variabel-variabel dari objek yang diteliti, guna menghasilkan kesimpulan-kesimpulan yang digeneralisasikan (Zaini, 2018). Metode penelitian yang dipilih dalam penelitian ini untuk mengetahui respon penonton pada sosialisasi literasi sains 
Family Sanitary tentang tips mencuci tangan dengan sabun. Respon dalam hal ini berarti jawaban, balasan, atau tanggapan (Reaction). Menurut (Anggi: 2011) respon akan muncul dari penerimaan pesan setelah terjadinya serangkaian komunikasi atau dapat diistilahkan dengan feedback (umpan balik) yang dapat berpengaruh besar dalam menentukan baik atau tidaknya suatu komunikasi.

Penelitian ini mengambil lokasi/ setting di situs YouTube, khususnya pada video diakun Youtube Tadris IPA IAIN Kudus yang diunggah pada bulan Juli 2020. Respon penonton akan dianalisis menggunakan analisis konten di Youtube. Yang pengambilan datanya melalui situs YouTube Studio. Teknik pengumpulan data yang dipergunakan dalam penelitian ini, yaitu jumlah like, dislike, grafik viewers, durasi rata-rata di penonton, jenis sumber traffic, sumber traffic eksternal maupun internal, umur dan gender penonton serta komentar. Semua data tersebut merupakan bentuk mekanisme interaksi social yang dapat dilakukan.

\section{Hasil}
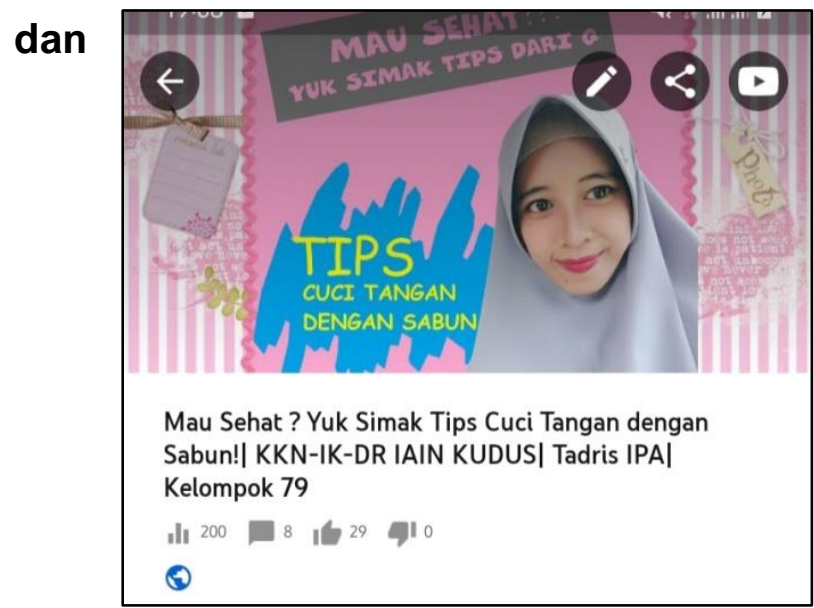

\section{Pembahasan}

Gambar 1. Konten Video

Data yang akan dibahas pada penelitian ini bersumber dari salah satu video vlog di Channel Tadris IPA IAIN Kudus yang berjudul "Mau Sehat? Yuk simak Tips Cuci Tangan dengan Sabun". Vlog ini dibuat oleh Malia Afidatus Shofa mahasiswa dari Program Studi Tadris IPA IAIN Kudus. Pada vlog ini mendapatkan 200 viewers 8 komentar dan 29 like. 


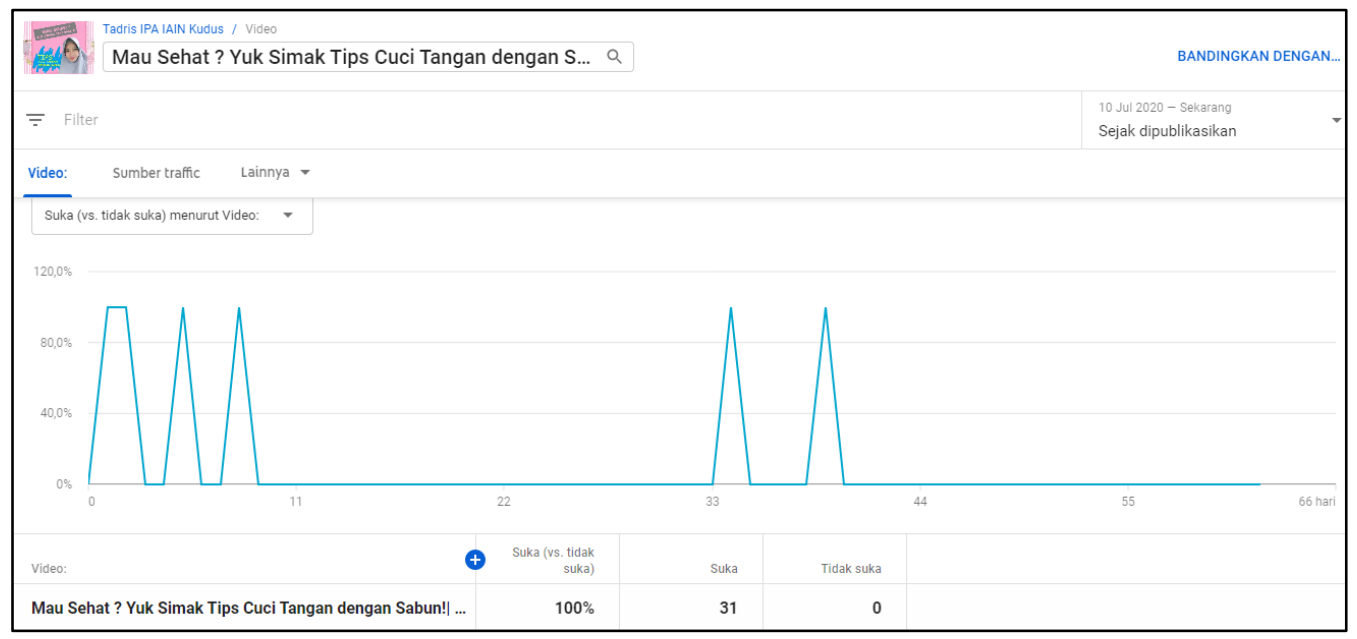

Gambar 2. Like dan Dislike

Video vlog ini memperoleh like dan dislike sesuai rincian gambar di atas. Persentase like yang didapatkan mencapai 100\% dengan perolehan 31 like dan 0 dislike.

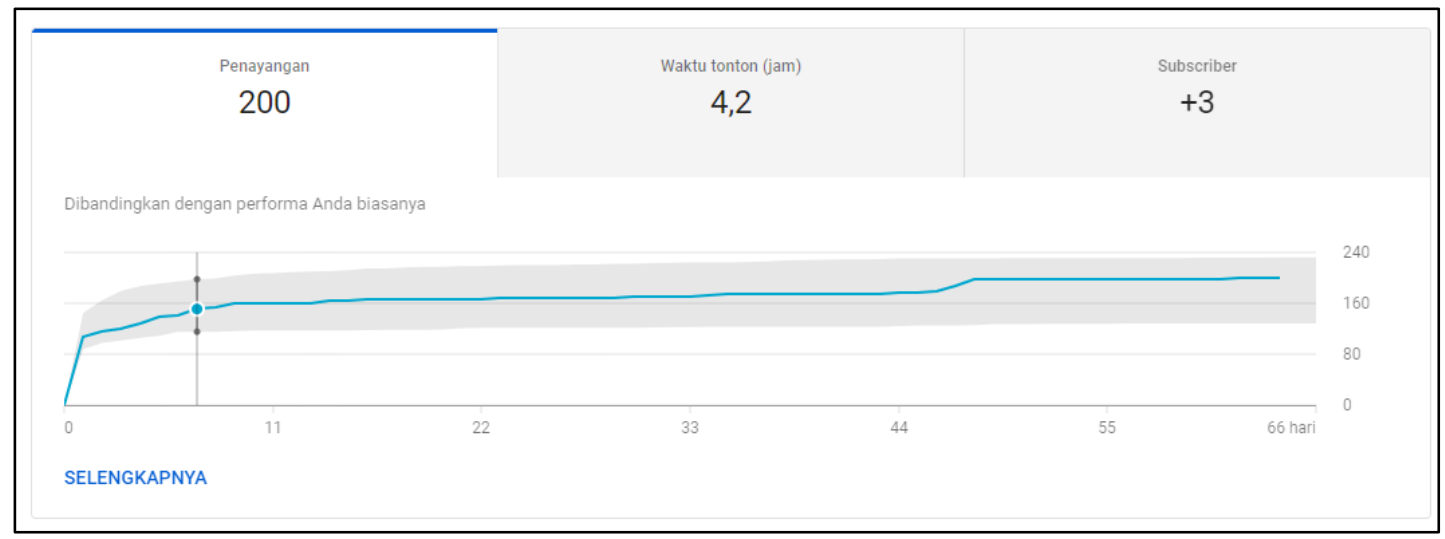

Gambar 3. Grafik Viewers

Dari data di atas Vlog ini mengalami peningkatan viewers selama 66 hari naik menjadi 200 viewers 


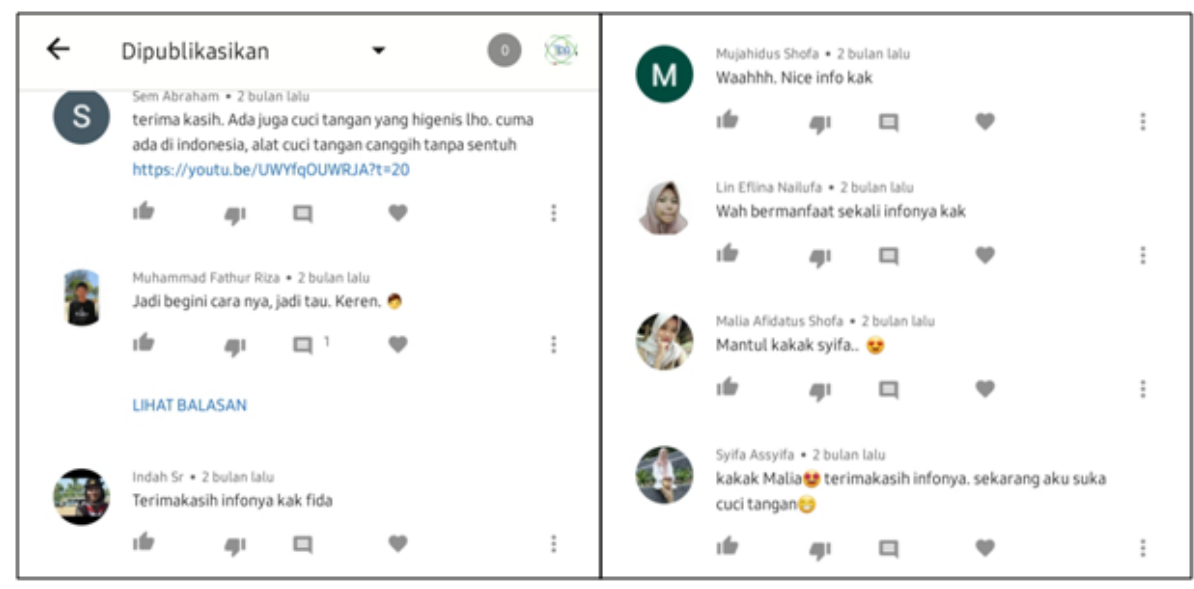

Gambar 4. Komentar

Komentar pada vlog ini mendapatkan total 8 komentar. Komentar ini sangat beragam mulai dari memberikan pujian bahkan sampai gurauan dan ada juga yang iklan konten youtube.

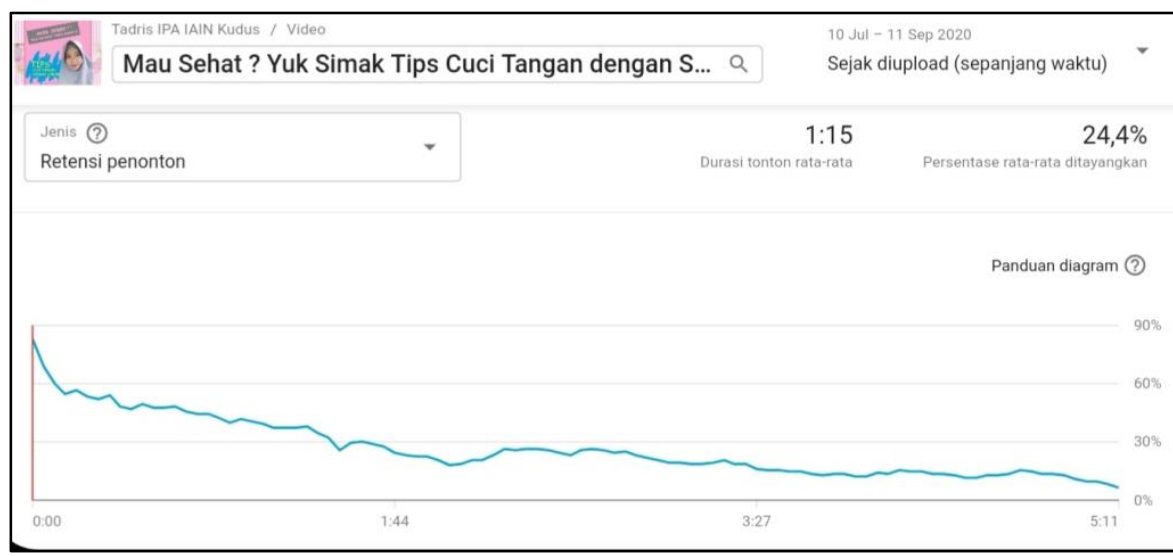

Gambar 5. Durasi rata-rata ditonton

Persentase rata-rata lama penayangan vlog kali ini mendapat
$24,4 \%$ atau selama 1:15 detik dengan total lama video 5:11 detik 

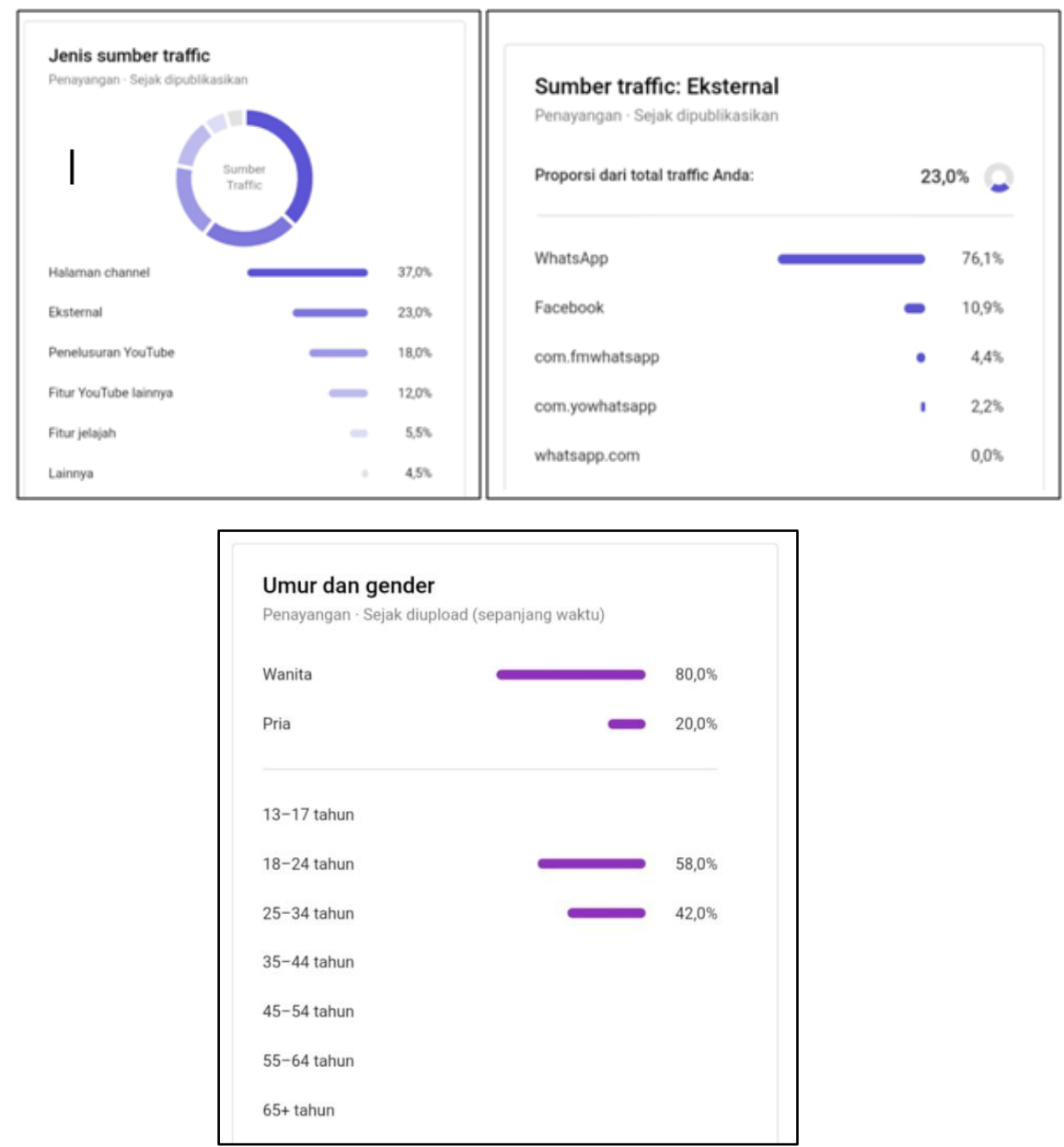

Gambar 6. Jenis Sumber Traffic. Gambar 7. Sumber Traffic Eksternal. Gambar 8. Umur dan Gender Penonton

Dari data (gambar 6), Perolehan viewers yang didapat vlog ini diperoleh dari berbagai jenis sumber. Jika dipersentasekan perolehan dari halaman channel sebanyak $37 \%$, dari sumber eksternal sebanyak $23 \%$, dari penelusuran youtube sebanyak $18 \%$, dari fitur youtube lainnya sebanyak $12 \%$, dari fitur penjelajah sebanyak $5,5 \%$ dan daru sumber lainnya sebanyak 4,5\%. Jika di analisis lebih rinci lagi pada (Gambar 7). Dari gambar 8, banyaknya viewers yang didapat bisa dirincikan berdasarkan gender dan umur. Dari data yang diperoleh terdapat $80 \%$ penonton perempuan yang berarti sekitar 160 penonton dan $20 \%$ penonton laki-laki sekitar 40 penonton. Hasil tersebut bisa dikatakan ketertarikan perempuan terhadap konten vlog yang dibawakan lebih tinggi dibanding dengan laki-laki. Dari keseluruhan penonton berasal dari kalangan umur 18-24 tahun. Maka dari sumber eksternal diperoleh sebanyak $23 \%$ dan dari platform Whatsapp di urutan teratas sebanyak $76,1 \%$ sehingga WhatsApp menjadi sumber info yang paling tinggi. Analisis data diatas menunjukan respon positif dari warganet, hal itu bisa dilihat dari komentar-komentar yang positif yang terlihat pada (gambar 4). Tetapi dari hasil grafik menunjukkan bahwa jumlah viewers selama 66 hari hanya meningkat menjadi 200 , meskipun dapat dikatakan meningkat tetapi hanya sedikit sekali peningkatannyadan total lama penayangan video rata rata hanya 
1,14menit. Hal tersebut dikarenakan kurangnya membagikan vidio tersebut pada sosial media lain sehingga belum banyakmasyarakat yang mengetahui vidio tersebut dan rata-rata penanyangan vidio juga rendah bisajadi dikarenakan vidio vlog tersebut kurang menarik ataupun kedala pada sinyal sehingga penonton memutuskan untuk keluar dari vidio. Jika dilihat dari jumlah like mencapai 31 dan unlike 0 dapat diartikan bahwa warganet menyukai video yang mereka lihat dan kemungkinan besar dapat meningkatkan jumlah viewer untuk kedepannya. Likedari masyarakat yang menonton vidio tersebut berarti masyarakat merasa video tersebut bermanfaat, sehingga kemungkinan masyarakat yang suka terhadap vidio tersebut dapat mendukung video tersebut menjadi viral nantinya. Sehingga dapat disimpulkan, jika jumlah like lebih tinggi like daripada dislikeberarti masyarakat menyukai vidio tersebut sehingga kemungkinan besar dapat meningkatkan jumlah subscribers.

Pada Jenis Sumber Traffichalaman channel menjadi urutan teratas dengan perolehan $37 \%$ berarti banyaknya penonton yang melihat vidio ini mendapatkan info dari halaman channel itu sendiri karena telah mengsubscribe channel tersebut.Dari sumber eksternal platform Whatsapp menjadi urutan teratas dengan perolehan $76,1 \%$ yang berarti banyaknya penonton yang mendapatkan info tersebut melalui platform WhatsApp. Hal ini bisa terjadi karena vlogger

\section{Kesimpulan}

Berdasarkan penelitian yang telah dilakukan melalui video vlog dari Malia Afidatus Shofa dengan judul "Mau Sehat? Yuk simak Tips Cuci Tangan dengan Sabun" ini mendapatkan 200 viewers 8 komentar membagikan video tersebut melalui tombol share. Share atau bagikan berarti suatu tindakan membagikan atau meneruskan video yang ia lihat kepada orang lain. Apalagi Whatsapp sebagai salah satu media social yang paling banyak digunakan, sehingga penambahan viewers akan terbantu melalui tombol share tersebut.

Ketertarikan penonton akan berpengaruh sebagai salah satu sumber pemikatan video. Hasil menunjukkan jumlah penonton perempuan sekitar $80 \%$ penonton dan laki-laki sekitar $20 \%$ penonton. Jumlah tersebut berarti perempuanmemiliki pemahaman dan ketertarikan yang kuat terhadap video pengelolaan sampah tersebut daripada laki-laki.

Berdasarkan hasil pemaparan diatas, dapat disimpulakan bahwa video tersebut mendapatkan respon positif dan diterima oleh kalangan Youtube yang terlihat dari komen positif dan like dari vidio tersebut, meskipun jumlah viewersmasih sedikit tapi tidak menutup kemungkinan untuk terus bertambah. Sosialisasi melalui video Youtube akan sangat membantu meningkatkan literasi sains warganet khususnya pada penerapan Family Sanitary.Sosialisasi tersebut diharapka masyarakat dapat mengerti akan kebersihan dan dapat dimulai dengan hal kecil yaitu cuci tangan walaupun hanya cuci tangan tetapi memiliki manfaat yang sangat besar.

dan 29 like. Capaian tersebut berasal dari sumber penonton paling banyak berasal dari WhatsApp yang di dominasi penonton dengan genre perempuan dengan usia penonton dari usia 18-24 tahun. Isi dari konten 
tersebut adalah memberikan tips mencuci tangan dengan sabun yang yang membahas cara mencuci tangan yang baik danbenar, apalagi di saat pandemi seperti ini yang mengharuskan untuk rajin mencuci tangan. Dan dari pemaparan tersebut dapat diambil kesimpulan bahwa didapat strategi sosialisasi melalui YouTube mendapat respon baik dari warganet. Meskipun jumlah viewers hanya meningkat sedikit tetapi respon baik tersebut terlihat dari komentarkomentar yang positif dari warganet dan juga like serta tanpa adanya dislike. Respon baik dari warganet tersebut diharapkan dapat menambah pengetahuan masyarakat tentang Family Sanitary yang dapat dimulai dari hal kecil seperti mencuci tangan. Respon baik dari warganet juga diharapkan dapat menambah jumlah vierwers untuk ke depannya.

\section{Acknowledgements}

Ucapan terima kasih ini penulis tujukan kepada:

Lembaga Penelitian dan Pengabdian Masyarakat IAIN Kudus selaku lembaga resmi yang selalu memberikan motivasi atas terlaksananya penelitian kali ini.

\section{Daftar Pustaka}

Anggaraeni, Rr Christiana Mayang. (2016). Hubungan Pengetahuan Sanitasi dan Higiene Dengan Sikap Siswa Kelas X SMK Negeri 6 Yogyakarta Di Laboratorium Boga. Skripsi: Universitas Negeri Yogyakarta.

Arnita, Ayu. (2011) . Gambaran Sanitasi Lingkungan Di Dusun Bassiu Desa Gunturu Kecamatan Herlang Kabupaten Bulukumba. Fakultas IImu Kesehatan Universitas Islam Negeri Alaudddin Makassar.

Celesta, Almas Ghassani dan Nurul Fitriyah. (2016). Gambaran Sanitasi Dasar Di Desa Payaman, Kabupaten Bojonegoro tahun 2016. Jurnal Kesehatan Lingkungan . Vol 11. No 2.

Daud, Anwar. (2007). Analisis Kualitas Lingkungan. Healthy and Sanitation: Makassar.

David, Eribka Ruthellia dkk. (2017). Pengaruh Konten Vlog Dalam YouTube Terhadap Pembentukan Sikap Mahasiswa IImu Komunikasi Fakultas IImu Sosial dan 
Politik Universitas Saam Ratulangi. E-journal "Acta Diurna" Vol. VI. No. 1 Tahun 2017.

Kementerian Pendidikan dan Kebudayaan. (2017). Materi Pendukung Literasi Sains. Jakarta: 5

Martono dan Satino. ( 2015). Model Asuhan Keperawatan Komunitas Untuk Percepatan MDGs Sektor Perilaku Sanitasi Kesehatan. Jurnal Ners Vol. 10 No. 2 Oktober 2015: 301-307.

Mustikawati, Intan Silviana. (2017). Perilaku Cuci Tangan Pakai Sabun Studi Kualitatif pada Ibu-lbu di Kampung Nelayan Muara Angke Jakarta Utara: Studi Kualitaif. ARKESMAS, Volume 2, Nomor 1, Januari-Juni 2017.

Notoatmodjo, Soekidjo. (2005). Metodologi Penelitian Kesehatan, Rineka Cipta,Jakarta.

Puspitasari, Anggi Ria. (2011). Respon Siswa SMP Negeri 3 Kelapa Bangka Belitung Terhadap Film Laskar Pelangi. Skripsi. Jakarta: Universitas Islam Negeri Syarif Hidayatullah.

Roat, Charly dkk (2018). Gambaran Kesehatan Lingkungan Sekolah Di Wilayah Kerja Puskesmas Tongkaina Tahun 2018. Jurnal KESMAS, Vol. 7 No.5, 2018.

Sidhi, Alifia Nugrahani dkk. (2016). Hubungan Kualitas Sanitasi Lingkungan Dan Bakteriologis Air Bersih Terhadap Kejadian Diare Pada Balita Di Wilayah Kerka Puskesmas Adiwerna Kabupaten Tegal . Fakultas Kesehatan Masyarakat: Universitas Diponegoro. Jurnal Kesehatan Masyarakat vol 4, No. 3, Juli 2016.

Syarif, Jamal. Sosialisasi Nilai-Nilai Kultural Dalam Keluarga. Fakultas Tarbiyah IAIN Antasari Banjarmasin.

World Health Organization. (2020). Anjuran mengenai penggunaan masker dalam konteks covid 19.

Zaini, Riza Ahmad. (2018). Analisis Pesan Dakwah Dalam WEB SERIES PulangPulang Ganteng Episode 3-5 Di YouTube. Skripsi. Universitas Islam Negeri Sunan Ampel Surabaya. 